\title{
'Goat Beautiful of Voice': A Piyyut of Abraham ibn Ezra from Medinet el-Fayyūm, Egypt
}

\author{
Alex Harris | ORCID 0000-0003-0732-3614 \\ University of Michigan, Ann Arbor, MI, USA \\ alexdhar@umich.edu \\ Michael Zellmann-Rohrer | ORCID 0000-0002-5200-8480 \\ University of Oxford, Oxford, UK \\ michael.zellmann-rohrer@classics.ox.ac.uk
}

\begin{abstract}
This zuta provides an edition of a new copy of a known piyyut by Abraham ibn Ezra,

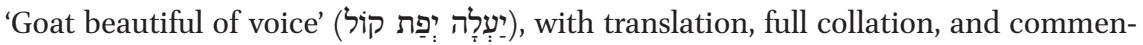
tary. This copy, now in the collection of the University of Michigan (P.Mich. inv. 531), offers some valuable new readings as well as evidence for the readership of Ibn Ezra in a provincial setting in medieval Egypt, as its provenance can be traced to the city of Medinet el-Fayyūm; the text can be added to evidence for a Jewish presence there, of which an overview is also given.
\end{abstract}

\section{Keywords}

piyyut - Abraham ibn Ezra - Egypt - vocalization - liturgy

\section{Introduction 1}

A paper sheet with a copy of a liturgical poem (piyyut) by Abraham ibn Ezra (1093-1167) is kept in the papyrus collection of the University of Michigan.

1 The authors thank Brendan Haug for permission to publish this text, Monica Tsuneishi for facilitating their access to it, and three anonymous reviewers of Zutot for helpful criticisms of the publication. Zellmann-Rohrer bears primary responsibility for the establishment and 
The poem, 'Goat beautiful of voice' (יעִלְה יְפַת קוֹל ), is previously known, and is included in the critical edition by Israel Levin on the basis of four copies. ${ }^{2}$ The poem is re-edited here on the basis of the new Michigan copy (P.Mich. inv. 531, henceforth M), which contributes readings of text-critical interest as well as testimony to the readership of Ibn Ezra in a provincial setting in medieval Egypt. After an introductory discussion of $M$, its critical significance, and its context of copying and use, we present an edition and annotated translation of the poem; the edition includes a full comparison with the other known copies based on a re-collation of the four manuscripts used by Levin.

\section{Provenance}

Internal records kept by the Michigan collection indicate the purchase by the American classicist Francis W. Kelsey and the British papyrologist Bernard P. Grenfell in March or April of 1920. ${ }^{3}$ Kelsey, in collaboration with an American missionary physician based in the Fayyūm region, David L. Askren, and with Grenfell, was engaged in buying papyri from several dealers around this time. ${ }^{4}$ An entry in Kelsey's diary allows greater precision: he acquired the present text on 27 February 1920 in Medinet el-Fayyūm from the widow of a once-prolific antiquities dealer, Mohammed Rafaa (or Rifaa)..$^{5}$ As no other Genizah documents are known to have been acquired from this dealer, who has no known

collation of the Hebrew text; Harris conducted an autopsy on the original and contributed to the discussion of linguistic features. Abbreviations for papyrological publications follow the checklist at http://papyri.info/docs/checklist.

2 Israel Levin, Shire ha-qodesh shel Avraham ibn Ezra (Jerusalem 1975) 1:217-219 no. 116. The poem was first printed by Akiva ben Yosef Eger, Diwân des Abraham ibn Esra mit seiner Allegorie Hai ben Mekiz (Berlin 1886) 58 no. 148 (whence I. Davidson, Thesaurus of Mediaeval Hebrew Poetry [New York 1924-1938] no. YUD-3166), from Levin's cod. ב.

3 Available via the Michigan APIS database at http://quod.lib.umich.edu/a/apis/x-5254. The information is based on the typed inventory list prepared by Arthur S. Hunt, October 1920, for the 1920 purchases ('purchased in Egypt ... in March and April, 1920'), where the present text is entered as 'Short Poem, 14 Cent.'

4 On Kelsey's activities, see J.G. Pedley, The Life and Work of Francis Willey Kelsey (Ann Arbor 2012); T.M. Hickey, A. Maravela, and M. Zellmann-Rohrer, 'Historical and Textual Notes on Magical Texts in the Papyrus Collection of the University of Oslo Library,' Symbolae Osloenses 89 (2015) 156-164.

5 Kelsey describes the purchase of 'two Greek fragments and Greek, Coptic and Hebrew smaller pieces' from the collection of 'the widow of Mohammed Rafaa' in Medinet el-Fayyūm, for 3 Egyptian pounds. In the entry for 26 February he mentions visiting the 'widow of Mahommed Rifaa [sic], who had 25 boxes of fragments, very filthy, being infested with vermin.' The diary is now kept by the Bentley Historical Library, University of Michigan, with the rest of Kelsey's papers (Francis Wiley Kelsey papers, Box 4). The other 'Hebrew pieces' are presumably the only other two texts in this language in the Michigan collection, inv. $53^{2}$ (further piyyutim, catalogued as 'Parts of Hymns, from a prayer book, 13/14 Cent.'; Zellmann-Rohrer is preparing an edition of this text) and 533 (Talmudic fragment). 
links with the context of such documents in Cairo, and Medinet el-Fayyūm, a relative backwater with respect to the Europe-facing antiquities trade, is not otherwise attested as an entrepot for Genizah documents, we may proceed from the assumption that the dealer picked up the text there.

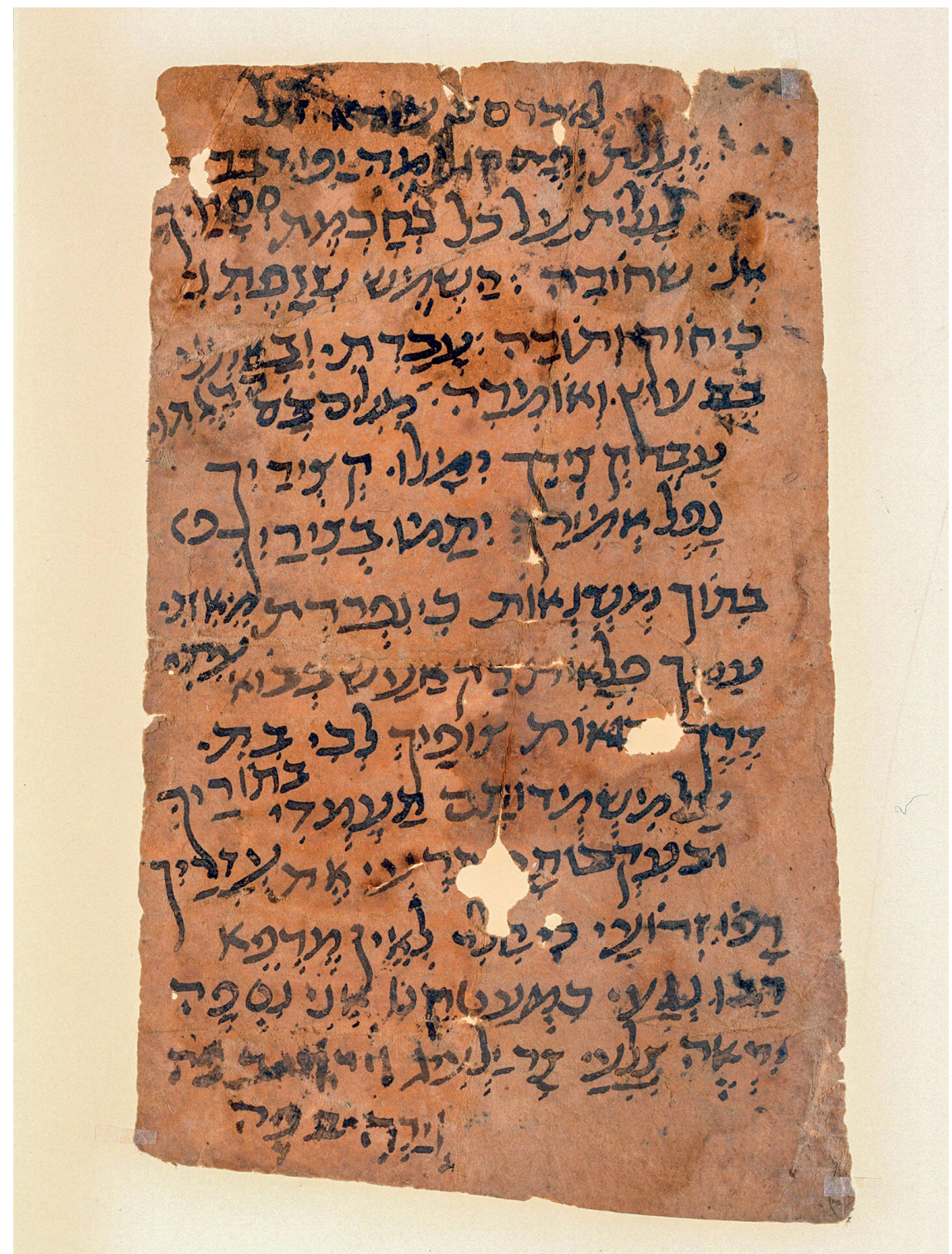

FIGURE 1 Ann Arbor, University of Michigan, Papyrus Collection, Harlan Graduate Library, P.Mich. inv. 531, front. Reproduced courtesy of the Papyrus Collection 


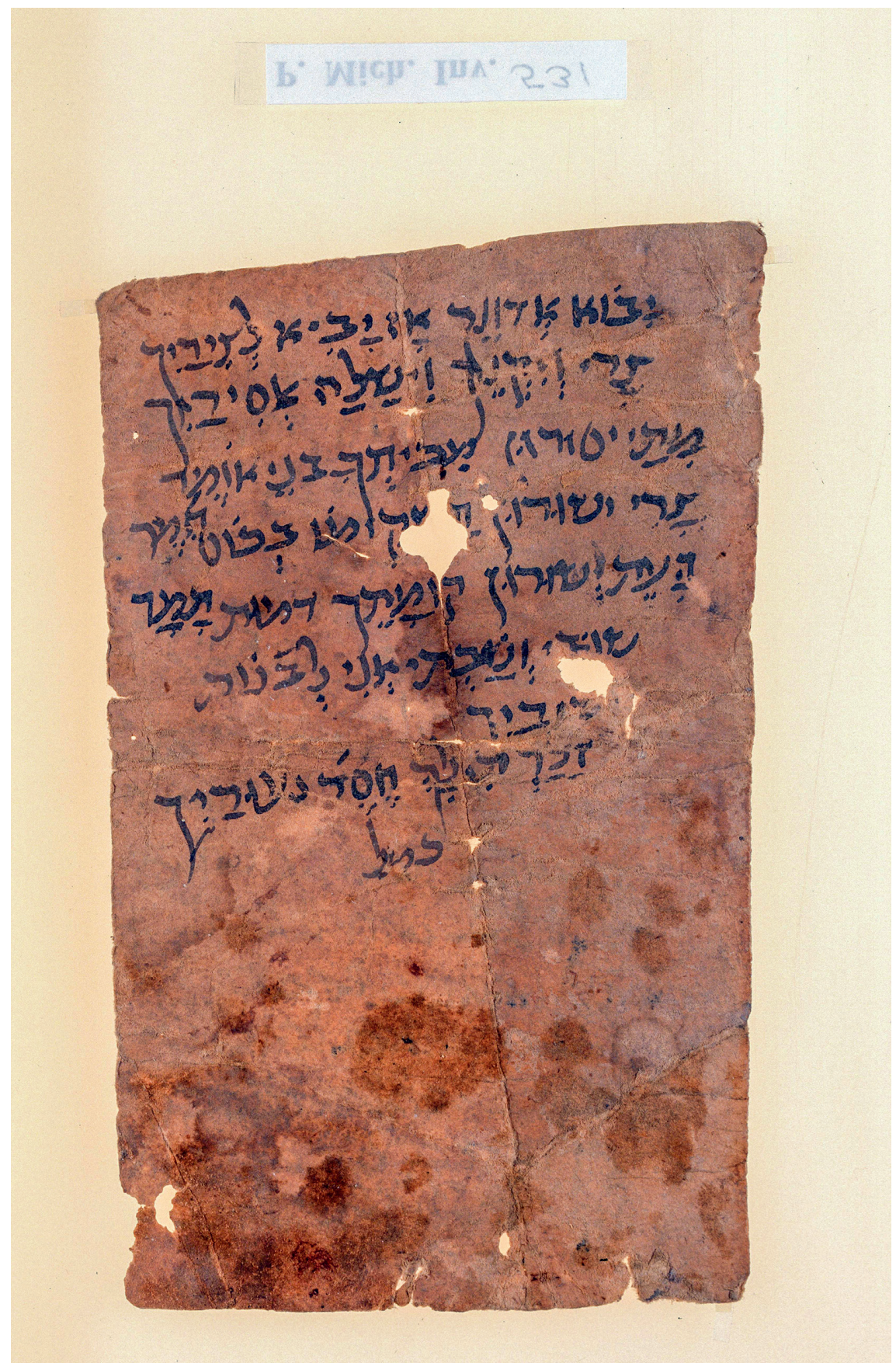

FIGURE 2 Ann Arbor, University of Michigan, Papyrus Collection, Harlan Graduate Library, P.Mich. inv. 531, back. Reproduced courtesy of the Papyrus Collection 


\section{Physical Description and Palaeography}

The text (Figs 1-2) is written in dark ink on both sides of a sheet of oriental paper ( $9.0 \mathrm{~cm}$ in width and $14.8 \mathrm{~cm}$ in height). The paper was flipped over the horizontal to continue the text on the back, and hence the sheet was meant as a stand-alone copy and not part of a codex. There are no visible wirelines or watermarks, ${ }^{6}$ and the lines are unruled. The semi-cursive, Mizrahic script is consistent with production in Egypt in the later 12th or 13th century. ${ }^{7}$ The hand is reasonably proficient with only slight ornamentation, most often of lamed. Raphe is used once (לְבנוֹ, line 22); three times the end of a first hemistich is marked with sof pasuq (4-6).

The scribe has added vocalization selectively, which presents a non-standard application of the Tiberian system, with frequent conflation of the quantity and quality of the /a/ and /e/ vowels. ${ }^{8}$ Compared with the standardized Tiberian vocalization of the poem as established by Levin, the M copy offers some interesting divergences, which probably reflect a local, Egyptian pronunciation colored by Arabic. Particularly common is the replacement of patah (v) with segol $(\varepsilon)$, characteristic of Mizrahic Hebrew, under the influence of Arabic. This development is also common in Yemenite Hebrew, which had even more limited contact with the West. ${ }^{9}$ In $\mathrm{M}$ the hatef vowels are also frequently simplified to shewa, a development likely related to the lack of such vowels in Arabic.

6 This feature is typical of local production in an oriental context. See M. Beit-Arié, Hebrew Codicology: Tentative Typology of Technical Practices Employed in Hebrew Dated Medieval Manuscripts (Jerusalem 1981) 29.

7 A. Yardeni's 'semi-cursive "Eastern" script from Egypt' (The Book of Hebrew Script: History, Palaeography, Script Styles, Calligraphy \& Design [Jerusalem 1997] 220-221), comparable to the documentary hands in S.A. Birnbaum, The Hebrew Scripts (Leiden 1971) nos. 177 (Oxford, Bodleian Library Ms Heb d 66, fol. 78; $1161 \mathrm{CE}$, Fustat) and 177* (Cambridge, University Library Add. MS 3417; 1232 CE, Fustat); compare also Cambridge, University Library Ms Or. 1080 3.2, dated to the 12-13th cent. by S.C. Reif, Jewish Prayer Texts from the Cairo Genizah (Leiden 2016) 59-68, and Cambridge, University Library T-S H8.79, 13th cent., ibid., 189-200.

8 On medieval vocalizations adhering only partially to the system of Ben Asher, see S.C. Reif, 'The Vocalization of a Piyyut in MS. Günzburg 1041, JQR 62 (1971) 12-19; Reif, Jewish Prayer Texts, 6; on the Palestinian system in particular, J. Yahalom, Palestinian Vocalised Piyyut Manuscripts in the Cambridge Genizah Collections (Cambridge 1997). A good example of the interchange of $/ \mathrm{a} /$ with /e/ vowels, found frequently in $\mathrm{M}$ and probably reflecting contemporary pronunciation, are the prayers in the 13th-century codex fragment in Cambridge, University Library T-S H8.79, with Reif, Jewish Prayer Texts, 189-200. See further A. Dodi, 'The Vocalization of a 13th Century Siddur,' Leshonenu 53 (1988-1989) 67-89 [Hebrew], for the interchange of qametz with patah and tzere with segol, and the mixing of Palestinian and Tiberian systems along with the writer's own pronunciation.

9 This feature may be a relic of the lack of distinction between patah and segol characteristic of the medieval Babylonian system of vocalization for Biblical Hebrew, on which see I. Yeivin, Hebrew Language Tradition as Reflected in the Babylonian Vocalization (Jerusalem 1985) 


\section{The Piyyut}

The piyyut is attributed to Abraham ibn Ezra, both in a title in the first line and in an acrostic seal formed by the first lines of each full stanza (אברם), the first

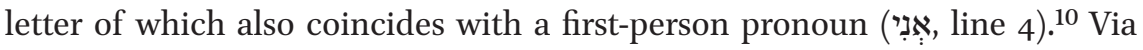
contextual information in another copy, Levin correctly identified the piyyut as an ahavah, among the poetic embellishments (yotzerot) associated with the liturgical benedictions attached to the shema $a^{\text {' for mornings. }}{ }^{11}$ The M copy gives no internal indications on liturgical background. The piyyut follows an originally Arabic strophic form, the so-called muwashshah, or 'belt,"12 with rhyme at both hemistich-ends, and twelve-syllable lines in a quantitative metrical pattern,

Along with its Arabicizing form, the present poem exhibits the fondness for alliteration and sound parallelism in roots and endings characteristic of Spanish piyyutim. ${ }^{13}$

[Hebrew] and A. Sáenz-Badillos, A History of the Hebrew Language (Cambridge 1993) 94-104, or once again due to Arabic influence.

10 As also in e.g. Levin, Shire ha-qodesh, 1:178-179 no. 95; on this device as characteristic of Spanish piyyutim, see L.J. Weinberger, Jewish Hymnography: A Literary History (London 1998), 97.

11 Attached to the phrase 'Who chooses his people Israel in love' (בבוחר בעמו ישראל) באהבה (באה פ פ פ the primary basis for Levin's edition (see the following section). The copy in ms ל improbably introduces it as a me'orah, attached instead to 'Creator of the luminaries' (יוצר המאורות) in the same morning liturgy. For both genres, see I. Elbogen, Jewish Liturgy: A Comprehensive History, trans. R.P. Scheindlin (Philadelphia 1993) 168-169.

12 On this form see recently the essays collected in F. Corriente and Á. Sáenz-Badillos, eds., Poesîa estrófica: Actas del Primer Congresso Internacional sobre Poesía Estrófica Árabe y Hebrea y sus Paralelos Romances (Madrid, diciembre de 1989) (Madrid 1991), especially the contributions of I. Levin, 'A Survey of the Muwaššạ and Its Various Strophic Variations in the Religious Hebrew Poetry in Spain,' 225-231 and J. Yahalom on the reception of the form in Egypt, 'The Context of Hebrew Imitations of Muwaššahāt in Egypt,' 357-366; and in E. Emery, ed., Muwashshah: Proceedings of the Conference on Arabic and Hebrew Strophic Poetry and its Romance Parallels, School of Oriental and African Studies [SOAS], London, 8-10 October 2004 (London 2006), especially the contribution of A. Schippers, 'Some Remarks on the Muwashshahāt of Abraham ibn Ezra,' 241-255. For further literature: H. Heijkoop and O. Zwartjes, Muwaššah, Zajal, Kharja: Bibliography of Strophic Poetry and Music from al-Andalus and Their Influence in East and West (Leiden 2004). Weinberger, Jewish Hymnography, 99-100; on Spanish piyyutim in general, ibid., 87-135. 
Following Levin, the content may be identified as a 'conversation' (שָׁיחה) in the form of a dialogue between two lovers, an allegory for the people of Israel (the woman) and their God (the man) in the tradition of the Song of Songs and its later exegesis. ${ }^{14}$ Levin assigns the opening couplet to God, as well as the second full strophe and the final couplet of the last, and the rest to Israel. The version of $\mathrm{M}$ requires a different division in the final strophe, between the first two lines for Israel and the final three for God.

\section{Text-Critical Significance}

Levin's edition took account of four copies:

ב = Berlin, Staatsbibliothek zu Berlin, Ms. or. fol. 1233, fol. 39a: a Yemenite Siddur manuscript, on which Eger based his edition (Diwân, pref., xi); purchased by the Königliche Bibliothek in Berlin from Moses Wilhelm Shapira in 1881; re-collated here from a digital facsimile provided by the Staatsbibliothek.

9 = Frankfurt am Main, Stadtbibliothek, Genizah fr. 34, fol. 2a: defective and now destroyed, see Levin, Shire ha-qodesh 1:18; re-collated here from a digital facsimile of black-and-white photographs provided by the Friedberg Genizah Project / Schocken Institute.

$\zeta=$ London, British Library Ms Or. 2587, fols. 45a-46a: a Siddur manuscript acquired by the British Museum from the same Moses Wilhelm Shapira in 1882, dated to the 15th century on the basis of palaeography and probably Eastern, ${ }^{15}$ re-collated here from a digital facsimile provided by the British Library. The manuscript includes additional text rejected from Levin's edition after line 17 (see the commentary below).

14 On such themes of present exile and hope of future redemption, informed on both conceptual and phraseological levels by the Song of Songs, as characteristic of Spanish piyyutim, see Weinberger, Jewish Hymnography, 11 and 100-104, including allusive instances where, as here, the speakers are not directly identified; and for the relation of earlier piyyutim to the Song of Songs, L.S. Lieber, A Vocabulary of Desire: The Song of Songs in the Early Synagogue (Leiden 2014) esp. 3-9o.

15 G. Margoliouth, Catalogue of the Hebrew and Samaritan Manuscripts in the British Museum (London 1899-1935) 2:388-39o describes the hand as '[h]ispano-oriental'; information on provenance comes from the British Library's digital catalogue. 
$\Omega=$ a Yemenite Tiklal manuscript in a private collection in Jerusalem, fols. 233b-234a, edited by Levin on the basis of a facsimile published by J.S. Hobareh, Sefer ha-Tiklal (Jerusalem 1964), which has been re-collated here; see also Levin, Shire ha-qodesh, 1:17.

Levin's text is based primarily on 9 where extant (lines 1-17; henceforth transliterated, as with the rest of the sigla, as F). Besides the alternate division of parts in the dialogue mentioned in the previous section, $\mathrm{M}$ contributes good, and in part arguably superior, readings at lines $5,9,12,14$, and 21 (in Levin's numbering 4, 8, 11, 13, and 20):

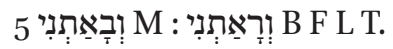

The more difficult reading offered by $\mathrm{M}$, involving a rarer but more pointed verbal construction for attack and the onset of calamity, is correspondingly less likely to have arisen as a banalization and has biblical parallels. ${ }^{16}$

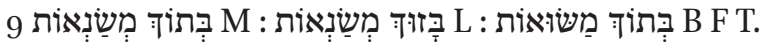

The reading of L, which removes a metrical fault, was wrongly dismissed by Levin and is now supported in part by M. The reference to 'enemies' already suggested by L ('enemies have despised you') is paralleled by a promised

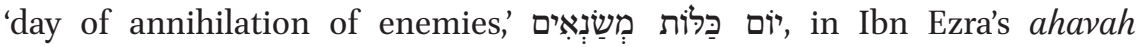

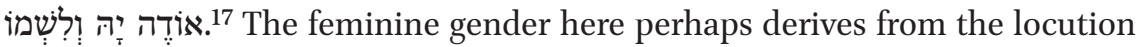

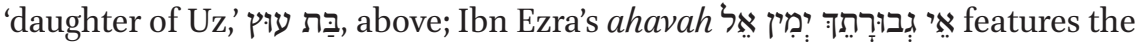

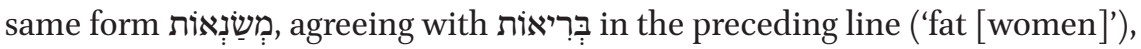
figuring the mockers of Israel. ${ }^{18}$ The reading of B F T ('amid burdens') probably represents a banalization.

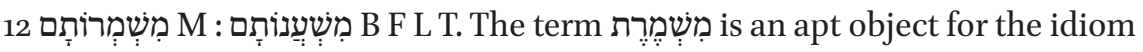
עָמֵמד עַל , proper to the occupation of a priestly office, ${ }^{19}$ and the present form

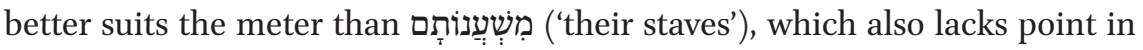
the context.

16 Compare e.g. Ps. 44:18, 'all this has come upon us,'

17 Edited by Levin, Shire ha-qodesh, 1:172-173 no. 92, line 15 .

18 Levin, Shire ha-qodesh, 1:183-185 no. 98, line 5.

192 Chron. 7:6, 8:14, 35:2 with D.J.A. Clines, The Dictionary of Classical Hebrew, 8 vols. (Sheffield 1993-2016) [henceforth DCH] 5:547-549 s.v. מִשְׁמֶרֶת. 


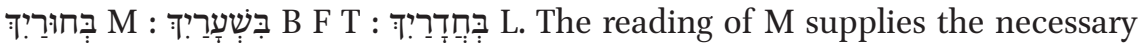

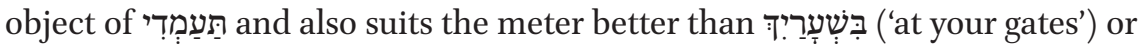
('in your bed-chambers').

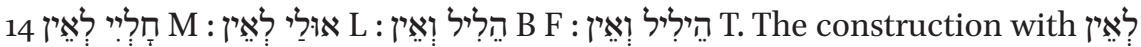
has a biblical parallel and is also used by Ibn Ezra in at least one other piyyut. ${ }^{20}$

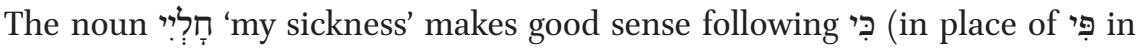
B F, as also in L T) and is perhaps preferable, in view of the following men-

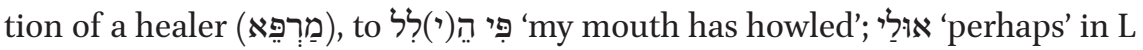
lacks point.

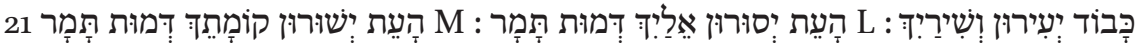

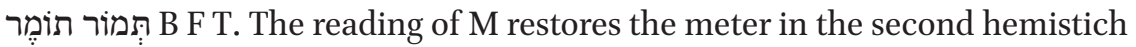
(as that of L, 'Now they shall turn [for refuge] to you like a palm'); the simile of the palm for the beloved as expressed in $\mathrm{M}$ has a close scriptural parallel in

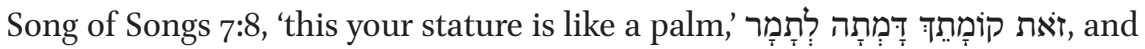
responds more generally to the floral metaphor of the taunt introduced in 8 .

The copyist of $\mathrm{M}$ has also made two corrections, one of which likewise bears text-critical significance. The first is trivial (line 16), probably a simple rewriting of text in which the ink had smeared. The second is of greater interest: a sign in the left margin to lines $7-8$, resembling two curved arrows, appears to indicate transposition of the second hemistichs of these two lines. That is, the scribe came at some point after writing to prefer an order in which the second hemistich of line 8 is read after the first hemistich of line 7 , and the second hemistich of line 7 after the first of line 8; the lines are therefore presented here in the order indicated by the correction. As there is variation among the other copies on precisely this point (see the edition below), the correction may be a sign that the writer has collated the copy with a second exemplar.

\section{Context of Copying and Use}

Abraham ibn Ezra, a native Spaniard considered one of the chief figures in medieval Hebrew poetry in Spain, spent a large part of his later life in unwilling

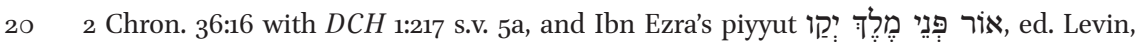
Shire ha-qodesh, 1:257-258 no. 138, line 8, 'the fruit-tree they have promised to destroy,

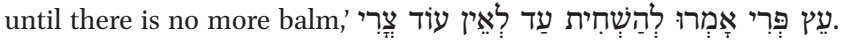


exile in various parts of Europe. ${ }^{21}$ Fittingly, his poetry and prose works, achieved a similarly international circulation. Many attestations of his liturgical poems are already known from the Cairo Genizah,,22 likely including the present poem (copy F), which was also read as far away as Yemen, having been taken up in prayer books along with many others of the poet's. M may represent a spread of that circulation farther into Egypt, beyond the urban centers of Cairo and Alexandria. For as mentioned above, there is little reason to suppose that the antiquities dealer who sold it in Medinet el-Fayyūm was responsible for its transportation to that city; even if it began life as an 'ordinary' Genizah manuscript, copied at or imported to Fustat, it will more likely have been a Jewish user who brought it south.

A Jewish presence at Medinet el-Fayyūm, consistent with use or even production of the M copy there, can be documented through historical sources. The city, and the Fayyüm region that it served as administrative capital, had an organized Jewish community attested from the Ptolemaic through the Roman periods, ${ }^{23}$ and in medieval times produced no less a luminary than Saadia Gaon, who was himself influential in the codification of liturgical prayer, among many other areas. At the time of the visit of Benjamin of Tudela (1130-1173), the region boasted a Jewish community considerable enough to attract the notice of the traveler, even though at only around 200 members it ranks among the smallest of those enumerated and is dwarfed by Fustat-Old

21 A summary of scholarship on Ibn Ezra, with bibliography and literary analysis of the poems, is provided by Y. Tobi, 'Abraham Ibn Ezra: The Poet,' Iberia Judaica 4 (2012) 105-126, and on the liturgical poems, 121-123; see further in general the essays collected in F. Díaz Esteban, ed., Abraham Ibn Ezra y su tiempo. Actas del Simposio internacional / Abraham Ibn Ezra and his Age: Proceedings of the International Symposium. Madrid, Tudela, Toledo, 1-8 febrero 1989 (Madrid 1990). The poetic corpus has also been anthologized by L.J. Weinberger, Twilight of a Golden Age: Selected Poems of Abraham Ibn Ezra (Tuscaloosa 1997) and I. Levin, Yalqut Avraham ibn Ezra (New York 1985) and Avraham ibn Ezra, Shirim (Tel Aviv 2011).

22 See the list in Levin, Shire ha-qodesh, 1:17-18; Tobi, 'Abraham Ibn Ezra: The Poet,' 106-107.

23 A synagogue was founded in the city, then Krokodilopolis/Arsinoe, in the 3rd century вCE. See C.Pap.Jud. I 134 and III 1532 (for the dedication-inscription itself, SB V 8939); a papyrus document dated to $116 / 117$ CE attests a Jewish quarter, with 'leaders'

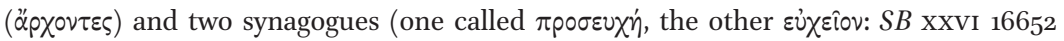
[P.Lond.Wasser.], lines 56-6o = C.Pap.Jud. II 432). Although the violent suppression of the Jewish Revolt no doubt affected this community, Jews did not disappear from the city, as seen in a contract from the 6th or 7 th century CE made out to an 'Abraamios, Hebrew, son

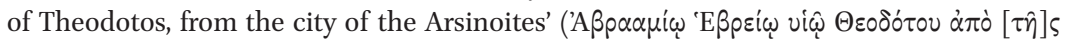

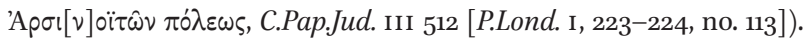


Cairo and Alexandria, with 7,00o and 3,00o respectively. ${ }^{24}$ From the following century, the account of Fahraddin 'Utman ibn Ibrahim an-Nabulusi asSafadi (1192-1261), an official who based himself in Medinet el-Fayyūm for over two months in the 1240s while surveying the Fayyum region on behalf of the sultan Salih Ayyub (1239-1249), contains a detailed description of the city and its communities, mosques, monasteries, and religious congregations, but no explicit mention of a Jewish presence. ${ }^{25}$ These 'congregations' (كَأس), however, of which the author counts 25 , though often rendered 'churches,' could conceivably include one or more synagogues: although none is marked explicitlyasJewish, the 'two Damascene congregations' (دمشقينكيستان) might be so identified.

Provincial though it may have been at the time $\mathrm{M}$ was copied, the community was in contact with the international literary currents by which the works of Ibn Ezra were so widely diffused, a connection to be added to the links previously known between the region and the major urban centers further north, attested in the Genizah documents. Among the examples that can be found in the documents surveyed by Shelomo D. Goitein, a few may be noted: a community of Jewish glassmakers in the Fayyumm region is attested in a Genizah letter of the Nagid Mevorakh b. Sa'adya, who was exiled there for a time in the 108os; a married Jewish man from Alexandria eloped to the region with a Cairene slave-girl, the subject of a query submitted to Maimonides; a Jewish tax-farmer working in the region was imprisoned after falling short in his collections; a letter sent from a small Jewish community in the village of Qalaha on the Bahr Yusuf between the Fayyūm region and the Nile refers to devastation in the area in the 'pillaging of the Fayyūm' (nahb al-Fayyüm) probably during the civil

24 Benjamin of Tudela identifies the contemporary פיום on his itinerary with the biblical Pithom, and mentions a community of about 200 Jews and remains of ancient buildings erected by 'our ancestors' (M.N. Adler, The Itinerary of Benjamin of Tudela [London 1907] 97 [צ]; for the rest of Egypt, 68-78 [צו-קח]). On the Jewish presence in the medieval Fayyūm region, see further N. Golb, 'The Topography of the Jews of Medieval Egypt,' Journal of Near Eastern Studies 24 (1965) 259-260, 268, 270; N.A. Stillman, The Jews of Arab Lands: A History and Source Book (Philadelphia 1979) 46-53, 67-75.

25 Tärīkh al-Fayyūm wa-bilādih, edited by B. Moritz, Description du Faiyoum au VIIme siècle de l'hégire (Cairo 1899), chapter $8, r-r$ r. On the text, see further I. König, 'Die Oase al-Fayyūm nach 'Utmān ibn Ibrāhīm an-Nābulusĩ: Ein Beitrag zur Wirtschaftsgeschichte Ägyptens um die Mitte des 13. Jahrhunderts n. Chr.', Zeitschrift für Geschichte der Arabisch-Islamischen Wissenschaften 10 (1995-1996) 189-253; for the Fayyūm region in particular, G. Salmon, 'Répertoire géographique de la province du Fayyoûm d'après le Kitâb Târîkh Fayyoûm d'An-Nâboulsî,' Bulletin de l'Institut français d'archéologie orientale 1 (1901) 42-44; J.G. Keenan, 'Landscape and Memory: al-Nabulsi's Ta'rikh al-Fayyum,' Bulletin of the American Society of Papyrologists 42 (2005) 203-212. 
wars of 1069-1072; a copy of legal proceedings from the region in Hebrew, for the settlement of marital difficulties, is preserved from the late 1oth or early 11th century; a letter sent from the region accompanied a present of dates and chicken for the celebration of Yom Kippur. ${ }^{26}$ The increased distance from the Mediterranean in any case need not correspond to a lower intellectual level: the copying process for this particular text was careful enough to involve, probably, collation with a second exemplar (see above).

Uniquely among the known copies of the poem, $\mathrm{M}$ was clearly written as a stand-alone copy, and not part of a codex. This disposition, coupled with the extensive addition of vocalization, suggests that it may have been intended for liturgical recitation, perhaps primarily so, in addition to private study. Signs of this liturgical use may also include the non-standard vocalization, which likely reflects the copyist's speech, as would the Arabic loan-word כמל that marks the end of the copy (line 25). A parallel for the format can be found in another paper sheet with a liturgical poem by Ibn Ezra, "The time of my redemption is

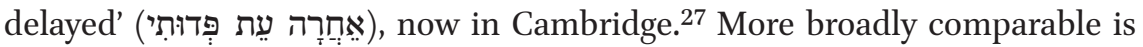
Cambridge, University Library T-S K 16.61, three liturgical poems by Ibn Ezra copied on the back of a draft of an Arabic official document, a petition to an Ayyubid ruler. ${ }^{28}$ Stefan Reif has identified this sort of informal copying of prayers as serving professional cantors, ${ }^{29}$ among others, one of whom might have been behind the present text.

26 S.D. Goitein, A Mediterranean Society. The Jewish Communities of the Arab World as Portrayed by the Documents of the Cairo Geniza, 6 vols. (Berkeley 1967-1993), 1:84, 134-135, 2:35 and 362, 3:207-208, 214-215, and 4:247, respectively. See also N. Golb, 'The Topography of the Jews of Medieval Egypt [continued], Journal of Near Eastern Studies 33 (1974) 127-128.

27 Cambridge, University Library Lewis-Gibson Misc. 57 (ex-Westminster College). This sheet is flipped over the vertical, not the horizontal, however. The manuscript represents a new copy of the poem with respect to the edition of Levin, Shire ha-qodesh, 1:206-208 no. 111. Recently the Lewis-Gibson collection was jointly acquired by the Cambridge University Library and Bodleian Library, Oxford, and will be divided between them; in the meantime digital facsimiles are available via the Friedberg Genizah Project.

28 For the document, see G. Khan, Arabic Legal and Administrative Documents in the Cambridge Geniza Collections (Cambridge 1993) 375-376 no. 92, dated to the mid-13th century (after 1238); the back was also used for additional redrafting of two sections of the petition. The poems are, in the edition of Levin, Shire ha-qodesh, 1:45-46 no. 22

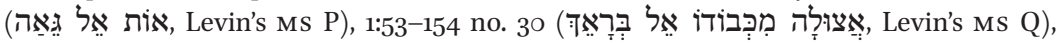

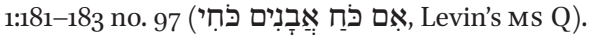

29 Reif, Jewish Prayer Texts, esp. 5 on copies of prayers as "no more than "cribs" to remind the worshipper what to recite and when'; commissions likely served 'a worshipper for a specific synagogal use' and 'a cantor or a teacher, or ... use within a family.' See in particular Cambridge, University Library T-S 6H6.6 fol. 4, discussed at 129-138, identified as the first folio of 'a small codex written by a cantor to provide guidance for himself' in leading prayer for Sabbath mornings. 


\section{Edition}

The text is presented with standard Tiberian vocalization. Variant vocalizations are noted infra.

Symbols used in the edition:

[] Letters lost due to damage

() Letters incorrectly omitted by the scribe

לאברם בן עזרא ז צל

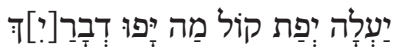

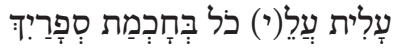

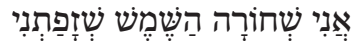

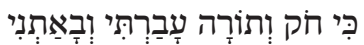

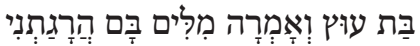

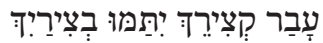

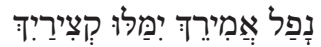

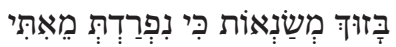
10

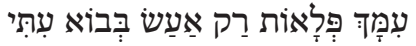

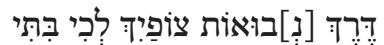

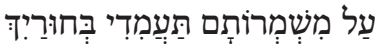

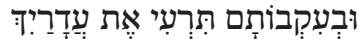

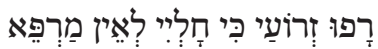
15

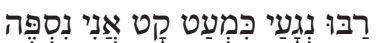

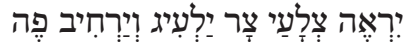

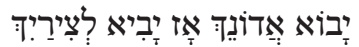

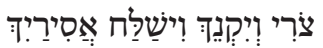

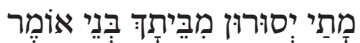
20

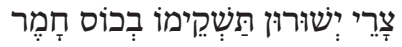

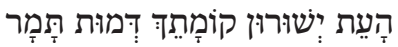

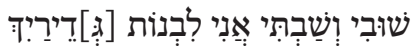

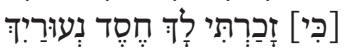

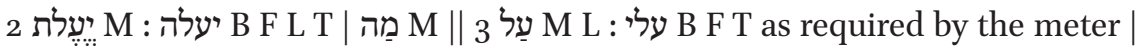

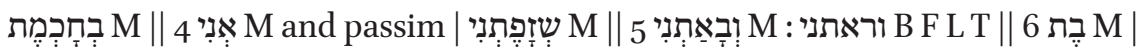

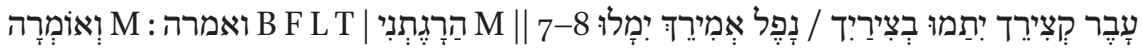




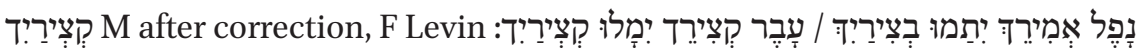

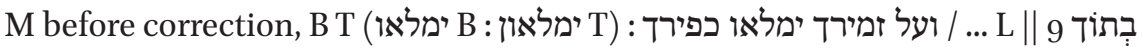

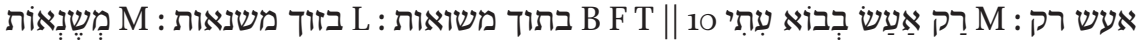

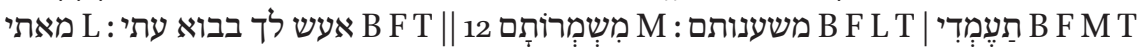

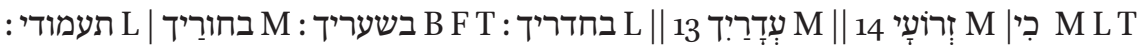

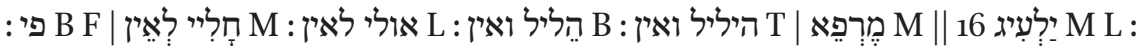
ילעג B F : omitted by T Tritten twice in M, only the second vocalized and probably a compensation by the scribe for blotting on the first attempt \|

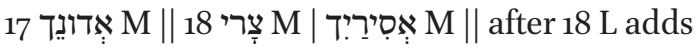

\section{הוחילי לי עוד אלבישך אדר עוד ותעלי אל ביתך ואל חדר אמך ודגלי עליך כמו עדר עזים שערך שער ראש נזיריך ראשך ככרמל הוא מלכך ושרי ושריך}

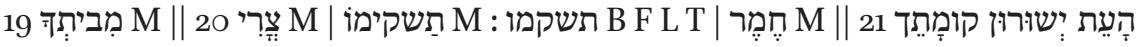

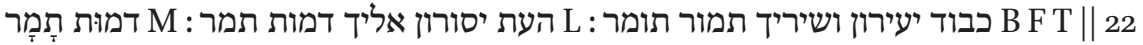
B B F L

\section{Translation}

Of Avram ben Ezra - may the memory of the righteous be a blessing

'Goat ${ }^{30}$ beautiful of voice, how beautiful are your words!

You have surpassed all in the wisdom of your books.'

— 'I am dark, the sun's gaze has lingered on me: ${ }^{31}$

For law and Torah have I transgressed, ${ }^{32}$ and there has come upon me The daughter of Uz, and spoken words wherewith she killed me: "Your grain harvest has passed away, your grape harvest is finished. ${ }^{33}$ Your crest has fallen, your branches wither."

30 יעִעָלה : specifically, a she-goat. The she-goat serves as term of address for the beloved in another ahavah of Ibn Ezra, ed. Levin, Shire ha-qodesh 1:219-221 no. 117, lines 1 and 18; from the Cairo Genizah, compare the anonymous piyyut edited by J. Schirmann, Shirim hadashim min ha-Geniza (Jerusalem 1965) 317-318 no. 197, where the address 'ruddy goat,'

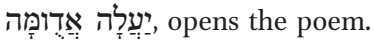

31 אִּנִ ... The image is drawn from Songs 1:5 and reflected also in Ibn Ezra's ahavah ed. Levin, Shire ha-qodesh 1:80-82 no. 45, lines 1-2.

32 חוֹק וְתוֹרָה

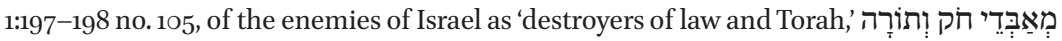
(line 6).

33 Levin compares the lament of the exiles in Jer. 8:20, "harvest-time has passed, summer has

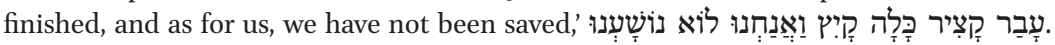


— 'Enemies have despised you, for you have been divided from me. I will work wonders with you only when my time comes.

Walk the path of the prophecies of your watchmen, my daughter: In their posts appoint ${ }^{34}$ your chosen ones, And in their footsteps tend your flocks.'

- 'My arms have gone slack, for my sickness is such that there is no cure. Many are my wounds, in only a little while ${ }^{35}$ I will be dead. A foe watches my stumblings, mocks, and opens wide his mouth, ${ }^{36}$ "Let your lord come, then for your pangs he will bring Balm, and redeem you, and release your prisoners." ${ }^{37}$

When ${ }^{38}$ will the sons of Omer depart from your house? The foes of Jeshurun, ${ }^{39}$ give them a foaming cup to drink! ${ }^{40}$

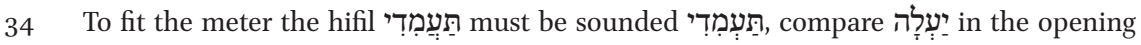
line.

35 כִמְעַט קָּט. From Ezek. 16:47, used elsewhere by Ibn Ezra in the piyyut ed. Levin, Shire

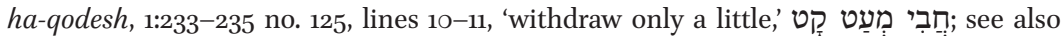

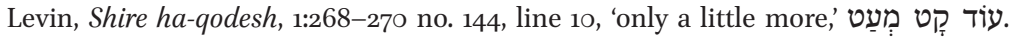

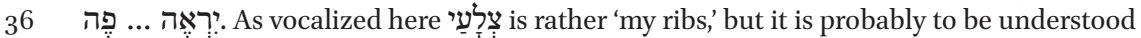

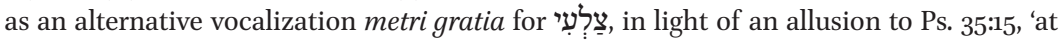

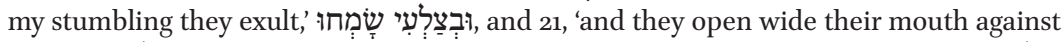

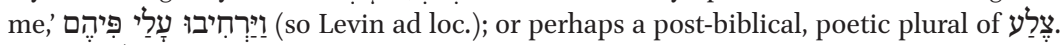

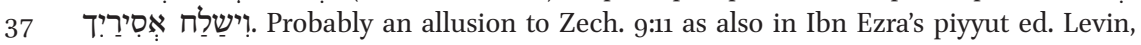
Shire ha-qodesh, 1:229-231 no. 123, line 15, 'your word will be confirmed, to release your

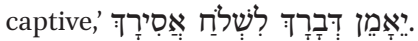

38 The additional text given by L between lines 18 and 19, found in no other copy and rightly excluded by Levin as inconsistent with the strophic form of the rest of the poem, may be translated as: 'Wait for me still, I will clothe you again in glory, and you will ascend to your house and your mother's chamber, and my banner will be over you. As a flock of goats is your hair, the hair of the head of your nazirites, your is head like Carmel, your king and your prince $<$ ? >.' For the figure of the banner compare Songs 2:4, for that of the flock of goats, ibid., 4:1, 6:5, and for that of Carmel, ibid., 7:6; for the mother's chamber also compare ibid., 8:2.

39 ישורוּן. The appellation is biblical (Deut. 33:26, Isa. 44:2), as also in Ibn Ezra's ge'ullah ed. Levin, Shire ha-qodesh, 1:348-350 no. 187, which opens, 'Let Jeshurun exult in their longing

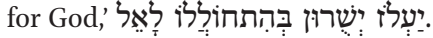

40 כוֹס חֶמֶר. The figure of the cup recalls Ps. 75:9 (a 'cup in the hand of the LORD and wine

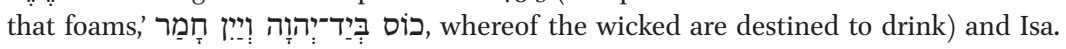

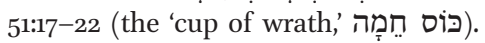


- 'When, Jeshurun, your stature is the like of a palm tree, Repent, and I myself will return ${ }^{41}$ to building your walls. ${ }^{42}$ For I have remembered for your sake the piety of your youth. ${ }^{43}$

\section{(The end.)}

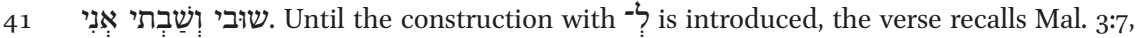

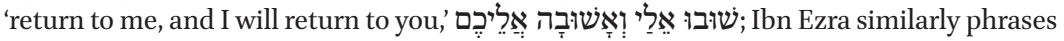
an exhortation of God in the person of the lover to Israel in the me'orah ed. Levin, Shire

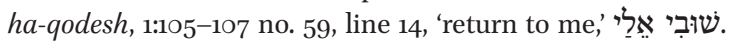

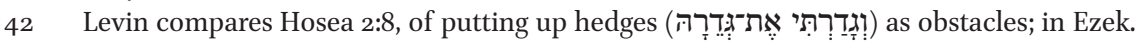
13:5 and 22:30, however, the hedge-walls appear instead as fortifications, which concords

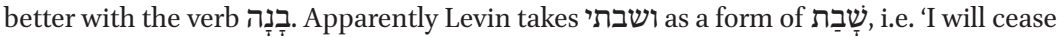

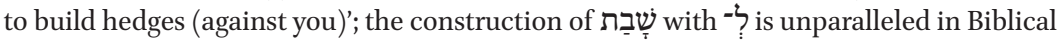
Hebrew, מִן being used instead, and hence a form of שוּב seems preferable, compare e.g

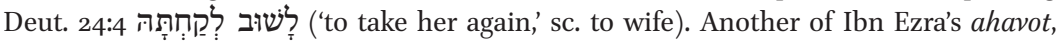
adduced here above in the note to line 4 (ed. Levin, Shire ha-qodesh, 1:8o-82 no. 45), has Israel in the figure of a woman asking her beloved, 'fence up the breach in my wall'

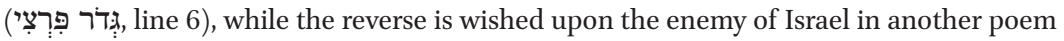

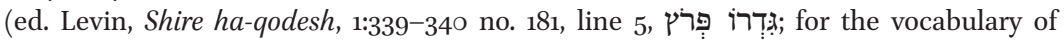
mending, see further the poems ed. Levin, Shire ha-qodesh, 1:225-227 no. 120, lines 8-9; 1:249-251 no. 134, line 22; and 1:254-256 no. 137, line 22).

43 זָכָרְתִי ... נעוּרַיריד The phrase is taken from Jer. 2:2, which Ibn Ezra likewise borrows for the final verse of another ahavah (ed. Levin, Shire ha-qodesh, 1:337-339 no. 180, line 17; for further adaptations see also Levin, Shire ha-qodesh, 1:184-185 no. 98, line 17; 1:203-204 no. 109; 1:210-213 no. 113, lines 29-30). 